\title{
The Ambatovy Project forest management program: a landscape approach to maintain biodiversity
}

\author{
B. Ramahavalisoa, J. J. Randrianirinarisoa, M. Rajaonarivony, \\ B. Rakotomanga, V. Mass \& P. Andrianaivomahefa \\ Environment Department, Ambatovy Project, Madagascar
}

\begin{abstract}
The Ambatovy Project is a nickel and cobalt exploitation operation that includes an open pit mine located near Moramanga, Madagascar, an area recognized for its high regional biodiversity. As a consequence, the Project has implemented a stringent biodiversity management plan for the conservation area surrounding the mine footprint which also overlaps with the neighboring Torotorofotsy Ramsar site. As part of its biodiversity policy and to adhere to "IFC Performance Standard 6 " on biodiversity conservation and sustainable natural resource management, the Project is committed to 1) avoiding species extinction, 2) minimizing impacts to natural resources, 3) realizing an actual net increase in the conservation of rare habitats, 4) assuring the viability of priority habitats by maintaining or increasing habitat connectivity, and 5) link Project actions in support of biodiversity with other regional biodiversity initiatives. To obtain these objectives, the Project has adopted a landscape approach to forest management that considers both the high level of biodiversity and the local population's dependence on natural resources as a means to sustain their livelihoods. As part of this approach, the Project is engaged in several activities including obtaining legal protection for a corridor linking the conservation area to the National protected areas system, providing support in updating the Ramsar site's management plan and creating a mine area forest zoning system that includes involving the local communities in forest management for sustainable resource use. Preliminary results suggest that activities implemented based on the landscape approach can be an effective means to decrease human pressure on areas of high conservation importance.
\end{abstract}

Keywords: biodiversity, mine, Madagascar, landscape approach, zoning, forest management, sustainable development. 


\section{Introduction}

The Ambatovy Project is a nickel and cobalt exploitation operation with an annual design capacity of 60000 tons of nickel and 5600 tons of cobalt over an expected lifecycle of 27 years. In addition, the Project will also produce 190000 tons of fertilizer (ammonium sulphate) as a refinery by-product. The Project comprises six major components; (1) the mine site, including a 4900 ha conservation area surrounding the footprint, (2) the $220 \mathrm{~km}$ slurry pipeline that transports ore from the mine to the plant site, (3) the industrial complex located near Toamasina that includes the processing plant and refinery, (4) the tailings facility, (5) the port extension and (6) the Ankerana offset site, a large (6800 ha) forest with similar biotic and abiotic conditions to those found at the mine site of which the Project aims to ensure long term protection (Figure 1).

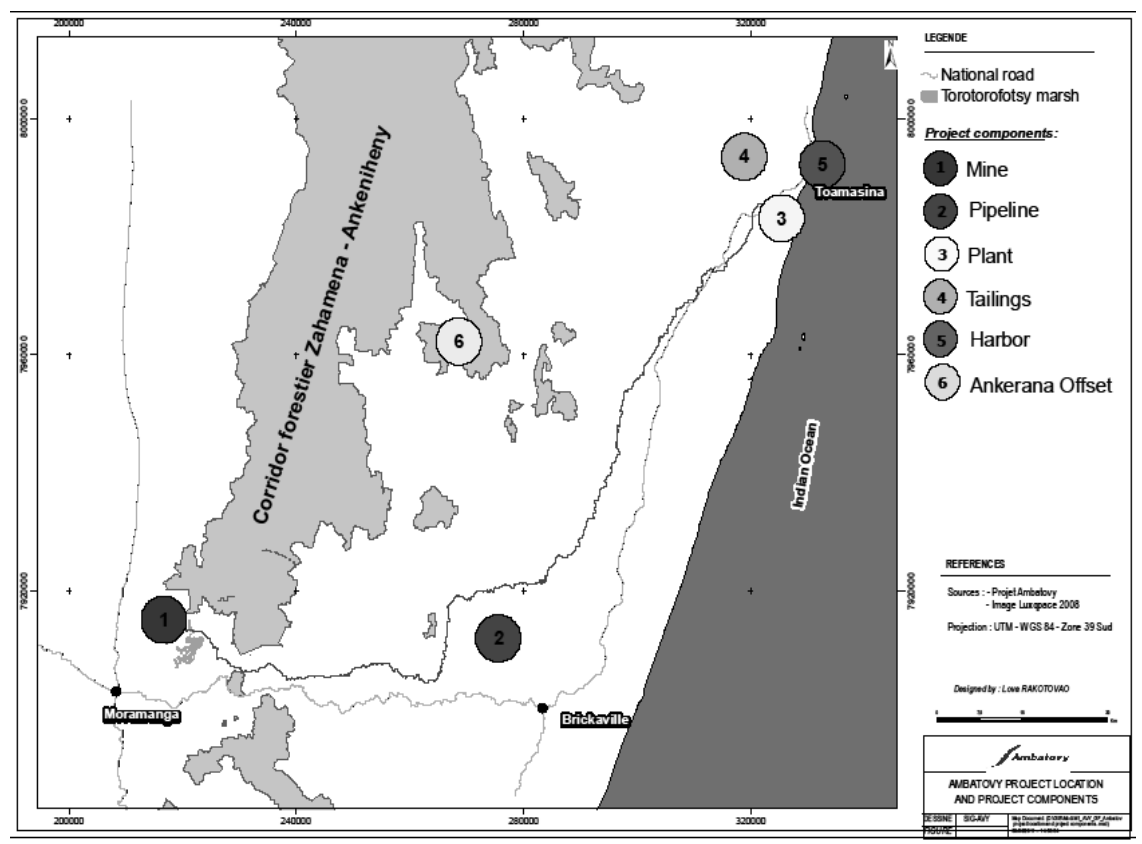

Figure 1: Major components of the Ambatovy project.

The open pit mine located near Moramanga, $130 \mathrm{~km}$ from the capital city of Antananarivo, lies within Madagascar's mid-altitude forest and is at the southwestern limit of the east coast rainforest corridor, the AnkenihenyZahamena forest corridor (CAZ). As this area is recognized for its high regional biodiversity [1], the Project has implemented a stringent biodiversity management plan. Moreover, the Malagasy environment decree [2] obliges all investment projects in Madagascar to comply with Malagasy environmental regulations and to conduct an Environmental and Social Impact Assessment (ESIA). Activities aimed to minimize biodiversity, physical and social impacts 
were derived from the ESIA and are included in the Environmental Management and Social Development Plan (EMSDP) [3]. The Project received its environmental permit in December 2006 [4].

The Ambatovy Project's vision states that it will operate a sustainable nickel / cobalt mining and processing enterprise that deliver outstanding environmental and social records', where sustainable refers to the management of the site in terms of social, economic and environmental gains post mining activities. The Project's principal financial lenders have subscribed to the Equator Principles. In this context, full regulatory compliance and the implementation of a thorough impact management strategy is expected. In addition, the Project complies with the International Finance Corporation (IFC) performance standard 6 [5] on biodiversity conservation and sustainable natural resource management. Therefore, as part of its biodiversity policy and to adhere to IFC performance standard 6, the Project has adopted five main goals including (1) avoid species extinction, (2) minimize impacts to flora, fauna and aquatic resources, (3) realize an actual net increase in the conservation of rare habitats, (4) assure the viability of priority habitats by maintaining or increasing habitat connectivity, and (5) link Project actions in support of biodiversity with other regional biodiversity initiatives [6].

\subsection{The mine region}

The mine is located to the south west of one of the largest protected areas in Madagascar, the Ankeniheny-Zahamena forest corridor (CAZ), which includes 371000 ha of eastern evergreen rain forest (Figure 2). This corridor is of high conservation importance due to high levels of biodiversity, species endemism and ecosystem function that this unique habitat can provide [7].

In order to promote regional connectivity, the Project is working towards linking the mine conservation area to the $\mathrm{CAZ}$ via a currently unprotected forest corridor, the Analamay-Mantadia forest corridor (CFAM). The objective is to maintain gene flow between the two forest blocks. In addition, this corridor includes the northern limits of the Torotorofotsy Ramsar site, an area known to harbor an important population of the critically endangered lemur, Prolemur simus [8, 9] (Figure 2). Moreover, studies have confirmed that a regional network of nature reserves might best perpetuate ecosystem integrity over the long term [10].

As the western area of the Ramsar site also overlaps with the mine lease area, the Project has supported the site through various activities such as updating the Ramsar site management plan and implementing a multi-disciplinary hydrological study of the Torotorofotsy watershed.

Finally, as this area (the mine conservation zone, the proposed corridor and Torotorofotsy) is located to the south of the CAZ, it can serve the function of protecting the CAZ from degradation activity from Moramanga, the town located in closest proximity to the southern limit of the CAZ (Figure 2). 


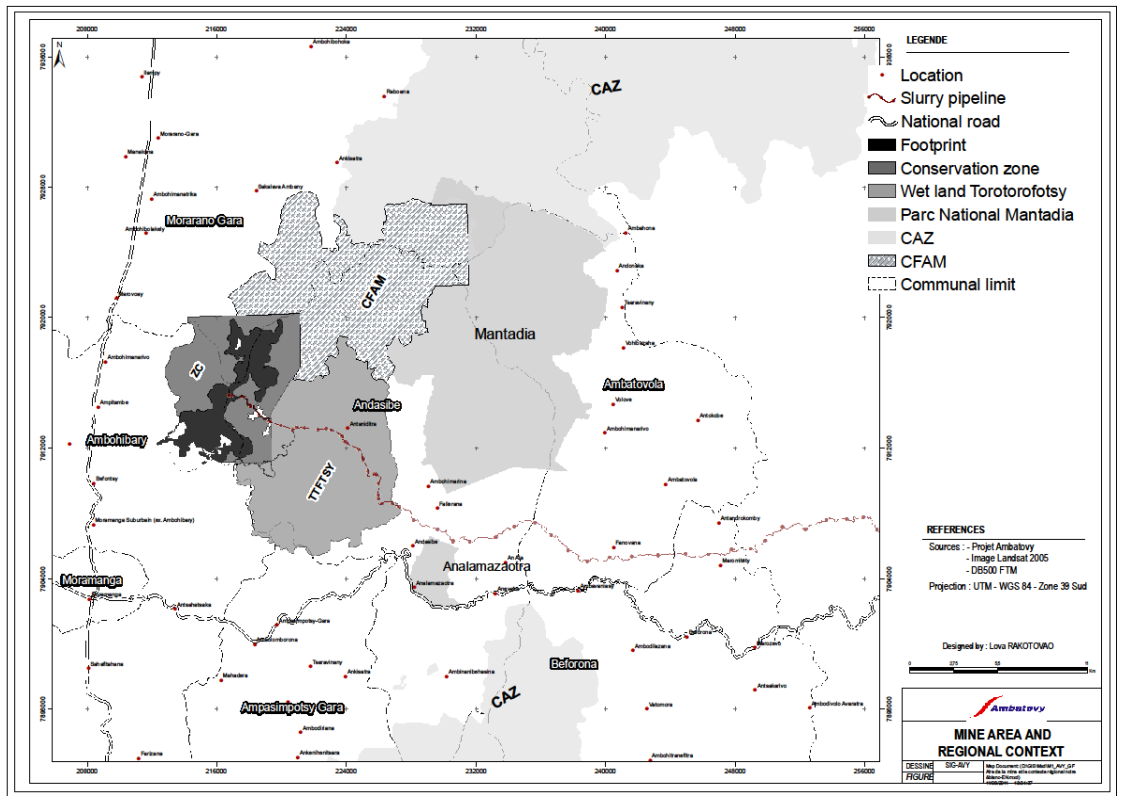

Figure 2: The mine region including the mine footprint and conservation zone, the Torotorofotsy Ramsar site, the CFAM and the CAZ.

\subsection{The mine area forest management plan}

The mine area, including the footprint and conservation zone, is located $130 \mathrm{~km}$ from the capital Antananarivo, in a forested area to the south of the CAZ (Figure 2). Forest clearing activities on the footprint were required for both the construction of mine infrastructure and exploitation. The conservation zone, 4900 ha of forest around the footprint, was established to ensure the long term conservation of forest similar to that found on the mine footprint and to maintain ecological services for the local communities. However, there are 93 villages located within the mine area of which the population still depends on natural resources for daily activities such as charcoal production, wood for cooking and house construction and water for both drinking and rice production.

In order to harmonize Project conservation commitments and the needs of the local population, the Ambatovy Project has adopted a landscape approach that takes into consideration the high level of biodiversity within the mine conservation zone forest, connectivity to surrounding protected areas and the dependence on natural resources by the local population as a means to sustain their livelihoods. As practiced in several countries in Africa such as Cameroon, central Africa and Gabon [11], the principals taken into account in the mine area forest management plan aim to address both conservation and development. Therefore, the overall objective of the management plan are to secure biodiversity conservation while decreasing pressure on natural resources within 
areas of high conservation importance by proving alternative income generating activities for the local population.

\section{Methods}

\subsection{Analamay-Mantadia forest corridor protection}

The Ambatovy Project is committed to maintaining or increasing habitat connectivity. In order to realize this commitment, several steps were taken to obtain legal protection for the Analamay-Mantadia forest corridor (CFAM) that links the mine conservation area to the CAZ.

The process to obtain legal protection for the CFAM was initiated in collaboration with Conservation International. As this corridor will be integrated into the Madagascar Protected Areas System (SAPM), the actions taken to create the CFAM follow guidelines proposed by the Malagasy Ministry of Environment and Forests.

Biological inventories, including a specific study on the distribution of Prolemur simus and its primary food resource, giant bamboo, were conducted by national experts in order to best define the boundaries of the CFAM for conservation. The presence / absence of fauna and flora species was determined using several methods, including direct observation, trapping (Sherman, pit fall traps and nets for fish), and transects. Moreover, interviews were conducted with the local population to confirm the presence / absence of several key species and to determine how the local population uses the natural resources present within the area $[12,13]$.

\subsection{Torotorofotsy management}

The Torotorofotsy Ramsar site overlaps with the Project's mine area to the east. Moreover, the slurry pipeline crosses through the northern area of the Ramsar site. Due to these factors, the Ambatovy Project has become an important stakeholder in the management of the Ramsar site. In this context, a memorandum of understanding with the Forest Service and the Ramsar site manager was signed in 2006.

Over the past several years, the Ramsar site has been subjected to a number of negative impacts including a significant increase in the number of people residing within the site with corresponding increases in land use, primarily for rice cultivation, and a decrease in total forest and marsh areas [14]. In response to these challenges, the Torotorofotsy management plan was updated based on flora, fauna, hydrology and socio-economic assessments made in 2008 [14]. In addition, a workshop aimed to resolve several main issues regarding the management of the site and to increase the awareness of the population located on or near the Ramsar site was conducted with the participation of various stakeholders (Ministries, local authorities, NGO's, conservation organizations, farmers organizations and the local community). The updated Torotorofotsy management plan was presented and validated during this workshop. Currently, 
a multi-component hydrology study including satellite image analysis, watershed basin dynamics modeling, soil studies, fauna species inventories and the quantification of species habitat requirements is underway. The results of this study will be used to define areas for habitat restoration and agricultural use and will guide future management decisions.

\subsection{Mine area forest management plan}

The main objective of the mine area forest management plan is to implement a forest management strategy that considers both conservation and sustainable resource use in the mine area thus contributing to regional development. The management strategy was conceived in partnership with the local population and in consultation with stakeholders. The strategies outlined to achieve this main objective were defined based on the identification of several main issues and take into account the Project's environmental commitments and long term vision for forest management.

\subsubsection{Mine area zoning}

Priority conservation areas, defined as areas where endangered species were inventoried, and areas of land used by the local population for their daily needs were identified during various surveys conducted within the mine area. In order to delimitate zones for future use by the local population and those for conservation, both estimated local population growth and endangered species home range requirements were considered. This information was combined with data on current land use to determine mine area zoning units [15].

The spatial distribution of the mine area zones was planned to take into account several key factors including connectivity of the conservation zones around the mine area, the location of villages and the presence of intact forest tracts with high species diversity which are considered priority areas for conservation.

In addition, local community management transfer zones were identified outside the conservation area. These zones, similar to the "green belt" concept, assure a buffer zone around the conservation area of which the local population can harvest natural resources. Six community management zones have been identified with the participation of the local communities concerned.

\subsubsection{Reforestation}

Wood is widely used by the local population within the mine area (Table 1). The collection of wood from natural forests also provides an opportunity for villagers to hunt both protected and game animals. In order to address deforestation and hunting issues, reforestation areas have been identified in the mine area zoning plan. The aim is to create a forest buffer zone between villages and the conservation zone that includes alternative wood sources in order to minimize pressure on natural resources and reduce illegal logging and hunting in the conservation area. 
Table 1: $\quad$ Wood use per household located in the mine area (in $\mathrm{m}^{3}$ ).

\begin{tabular}{|c|c|c|c|c|}
\hline Local community & Firewood & Construction & $\begin{array}{c}\text { Other } \\
\text { utilizations }\end{array}$ & Total \\
\hline Ampitambe & 21.6 & 6.26 & 0.07 & 27.93 \\
\hline Analalava & 13.59 & 6.26 & 0.07 & 19.92 \\
\hline Befotsy & 15.91 & 6.26 & 0.07 & 22.24 \\
\hline Menalamba & 14.32 & 6.26 & 0.07 & 20.65 \\
\hline Sakalava & 20.56 & 6.26 & 0.07 & 26.89 \\
\hline Ambohibolakely & 18.25 & 6.26 & 0.07 & 24.58 \\
\hline Marovoay & 22.33 & 6.26 & 0.07 & 28.66 \\
\hline Average & $\mathbf{1 8 . 0 8}$ & $\mathbf{6 . 2 6}$ & $\mathbf{0 . 0 7}$ & $\mathbf{2 4 . 4 1}$ \\
\hline
\end{tabular}

\subsubsection{Awareness programs}

River beds are often used by the local population for watercress culture and the banks cleared for vegetable crops. Similar uses of this habitat type have been found in the conservation area. Awareness programs and direct negotiations with local communities by the forest management, social and forestry service teams were conducted with the aim to stop watercress culture in sensitive aquatic habitats located in the conservation area.

In addition to the campaign to stop watercress culture in sensitive aquatic habitats, several other awareness campaigns have been conducted. The Project has identified four principal topics for awareness programs and plans to conduct these sessions at regular intervals each year. Sessions are conducted with village elders by Project representatives working in forest management with the aim of informing key village authorities who will transmit the message to the citizens residing in their communities.

\subsubsection{Patrols and infractions}

The conservation area around the mine covers a surface area of 4944 ha and plays an important role as a wildlife refuge for animals moving out of the mine footprint. At the beginning of construction in 2007, the population residing within the mine area had a low level of environmental education. This was mainly due to the low number of environmental groups existing in and around the mine area. In addition, the task force used to monitor impacts to conservation area habitat quality and integrity was in the initial stages of implementation. The aim of this task force is to conduct patrols of the conservation area and periphery forests while also raising the awareness of villagers they encounter on laws pertaining to forest use and hunting. While conducting patrols, the task force notes any infraction in the conservation area including instances of illegal logging, traps, fires and charcoal production. 


\section{Results}

\subsection{The mine region}

A total of 256 plant species and 175 fauna species were inventoried in the CFAM by national experts between January 31 and February 21, 2011. Of the species inventoried, 93\% are endemic to Madagascar. Moreover, 7 IUCN Critically Endangered, 5 Endangered and 8 Vulnerable species were observed [12]. The results of interviews conducted with the local population allowed for the identification of several main threats to the integrity of the forest corridor including slash and burn agriculture, manioc plantation, wood collection and gold mining. In addition, approximately 16 tons per year of plant leaves are collected from the corridor for essential oil production [13].

Based on these results, a preliminary recommendation for the corridor boundaries will presented to all stakeholders (local authorities, government ministers and scientific partners) for validation. Thus, the Project is in the final stages of corridor delimitation prior to obtaining legal protection.

Since the implementation of the updated Torotorofotsy management plan, several advances have been made to stop further deterioration of the Ramsar site marsh land. Land certificates have been awarded to 51 villagers that designate specific areas that can be used for agriculture and conservation obligations. Compliance with these obligations is monitored by the Malagasy Forestry Service (CIREF). Furthermore, in collaboration with the local authorities, a population survey, the first in the area, was conducted in December 2010 so that population growth can be better tracked and controlled.

The multi-disciplinary hydrological study has been validated and activities began in July 2011. First reports are expected in mid-September 2011. Information generated by this study will be used to rehabilitate the marsh land for biodiversity and to identify both necessary infrastructure and areas suitable for agricultural use by the local population.

Table 2: $\quad$ Forest management strategies and specific objectives.

\begin{tabular}{|c|c|c|}
\hline Issues & Strategies & Specific objectives \\
\hline \multirow{2}{*}{$\begin{array}{l}\text { Participatory } \\
\text { management of } \\
\text { natural resources }\end{array}$} & \multirow{2}{*}{$\begin{array}{l}\text { Facilitate local } \\
\text { management by } \\
\text { communities and the } \\
\text { local authorities }\end{array}$} & $\begin{array}{l}\text { Maintain the current state of forest } \\
\text { resources }\end{array}$ \\
\hline & & $\begin{array}{l}\text { Promote reforestation in collaboration with } \\
\text { the local population }\end{array}$ \\
\hline \multirow{2}{*}{$\begin{array}{l}\text { Management tools } \\
\text { are appropriate for } \\
\text { different } \\
\text { stakeholders }\end{array}$} & \multirow{2}{*}{$\begin{array}{l}\text { Develop activities for } \\
\text { conservation and } \\
\text { sustainable resource } \\
\text { use }\end{array}$} & $\begin{array}{l}\text { Develop activities promoting sustainable } \\
\text { natural resource use }\end{array}$ \\
\hline & & $\begin{array}{l}\text { Develop management tools to implement } \\
\text { conservation activities }\end{array}$ \\
\hline \multirow{2}{*}{$\begin{array}{l}\text { The environmental } \\
\text { reflex becomes a } \\
\text { habit }\end{array}$} & \multirow{2}{*}{$\begin{array}{l}\text { Develop a } \\
\text { communication } \\
\text { strategy for the forest } \\
\text { management plan }\end{array}$} & $\begin{array}{l}\text { Integrate the mine area management plan } \\
\text { into regional activities }\end{array}$ \\
\hline & & $\begin{array}{l}\text { Establish sustainable production among the } \\
\text { local population to protect forest capital }\end{array}$ \\
\hline
\end{tabular}




\subsection{The mine area forest management plan}

Based on consultations with the local population and principal stakeholders, six key objectives have been developed in order to address the main forest management issues concerning the mine conservation area (Table 2). These specific objectives have been used to identify 80 different activities that can occur within the mine area zoning units throughout the life of the Project.

\subsubsection{Zoning}

The outcome of various biological and social surveys has resulted in the elaboration of the mine area zoning plan consisting of 10 zone types. The zoning plan includes areas that serve a conservation function (28\% of mine area) including a core conservation zone and a controlled use zone, areas that serve an economic function $(26 \%)$ including the mine footprint, community use zones and agricultural zones, and areas that serve both conservation and economic functions (46\%) including a buffer zone around the mine footprint, and plantations for fruits and native trees (Figure 3). Conservation areas are grouped to the north and northeast of the mine footprint where forest tracts are still intact while the southern and western areas of the mine lease are dedicated to economic activities.

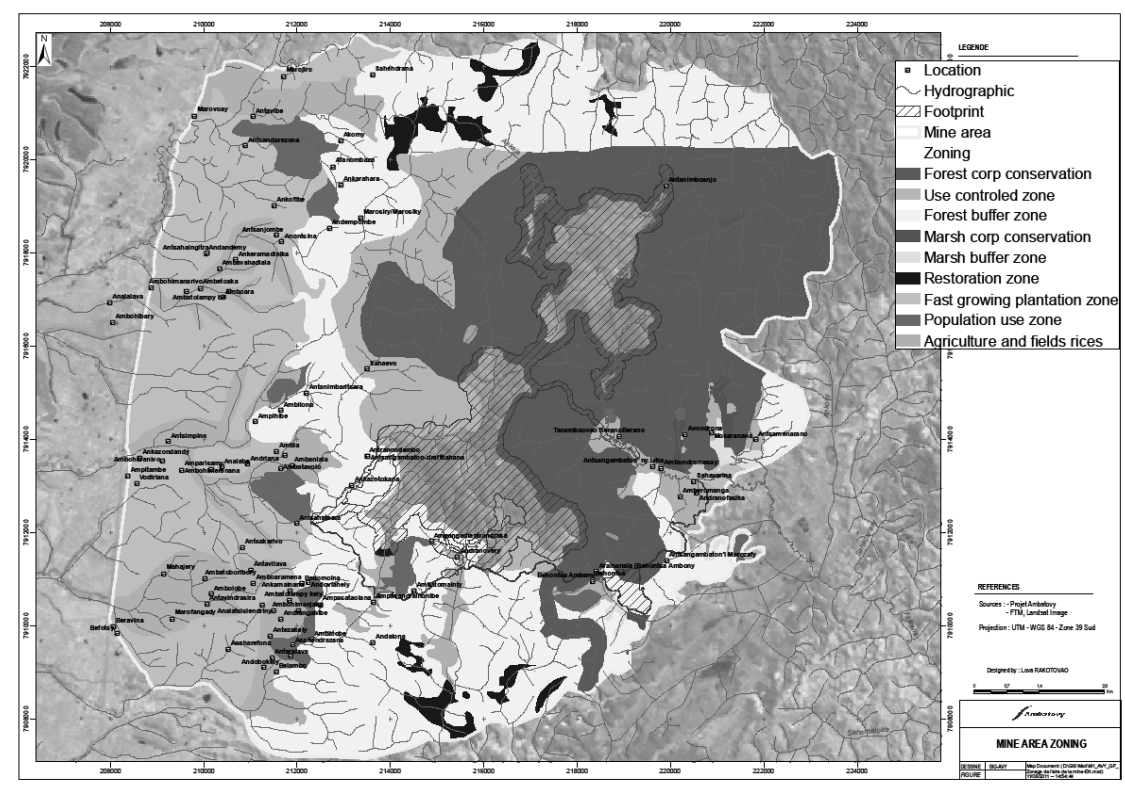

Figure 3: $\quad$ Mine area zoning.

Of the six community management zones identified, five management transfers have already been signed. A total of 3720 ha have currently been transferred to community management. These areas are located in the buffer zone type around the conservation area. The Project conducts regular monitoring of the community 
transfer zones to assure that they are being managed correctly in accordance to the management strategies provided. These local communities also use a traditional legal system called "dina" to assure that these areas are well managed. By using both traditional and modern approaches, the Project aims to assure that forest management obligations are understood and appreciated by all stakeholders.

\subsubsection{Reforestation}

In 2008, 32275 seedlings were distributed to local communities for use in reforestation. Based on the results obtained during the monitoring of these reforestation trials, the Project shifted its strategy from proving seedlings to the installation of production facilities. Within the mine area, two village nurseries are currently operational and three are in the process of being constructed. The aim is to provide communities with the necessary materials to produce seedlings for themselves and for future mine rehabilitation, and to strengthen the community's capacity in the production of young plants. The number of seedlings produced in these village nurseries since the onset of the program in 2008-2009 has increased (Table 3). Each participant has planted approximately 200 seedlings or an average equivalent to 125 acres per participant. The plantation success rate (plant survival) is similar to the national average of an $80 \%$ success rate [16].

Table 3: $\quad$ Seedling production in village nurseries.

\begin{tabular}{|c|c|c|c|}
\hline & $\mathbf{2 0 0 8 - 2 0 0 9}$ & $\mathbf{2 0 0 9 - 2 0 1 0}$ & $\mathbf{2 0 1 0 - 2 0 1 1}$ \\
\hline Participants & & 118 & 195 \\
\hline Seedlings produced & 32,275 & 29,050 & 32,452 \\
\hline Species & Eucalyptus robusta & Eucalyptus robusta & C camphora, Orange trees \\
\hline Area planted (ha) & 19.1 & 16.34 & 3.52 (to date) \\
\hline $\begin{array}{c}\text { Success rate } \\
\text { (plantation) }\end{array}$ & $63.70 \%$ & $79.12 \%$ & Ongoing \\
\hline
\end{tabular}

\subsubsection{Awareness programs}

In order to stop the practice of planting watercress in sensitive aquatic habitats, the Project held direct consultations with the local community. The negotiations resulted in the following resolutions:

- The population will work with the Ambatovy Project in natural resources protection within the conservation area;

- Training in vegetable crop production will be given by the Ambatovy Project, and will be applied to improve income-generating activities outside the conservation area;

- Support in acquiring production equipment will be provided by the Project for the production of vegetable crops outside the conservation area; and

- Watercress culture in conservation areas will be discontinued.

Training in vegetable crop production was conducted during a three day session at the "Centre de Formation Agricole de Betainomby » in Tamatave. Equipment, such as shovels, spades and watering cans, were also distributed with 
the aim of promoting the plantation of vegetable crops outside the conservation area. Finally, monitoring of crop production and discussions with the local community were conducted to identify constraints and possible solutions to achieve higher vegetable crop yields. Moreover, several participants have decided to join the ROSO NGO. This NGO acts as a vegetable supplier to the Project's central purchasing department. Of the 20 farmers trained, currently two are members of the ROSO association. In addition to providing vegetables to the Project, 16 farmers also produce vegetables for personal consumption and local sale.

In addition, four awareness programs have been conducted every three months since 2008. Topics include bushmeat and hunting laws, information on conservation area boundaries, fire management and use for agriculture and mine region conservation rules and regulations. These sessions have been held for all 93 communities found within the mine area.

\subsubsection{Patrol and infraction}

Since the implementation in late 2008 of a task force that conducts patrols in the conservation area, the number of traps, instances of illegal logging and charcoal production found within the conservation area has decreased (Figure 4).

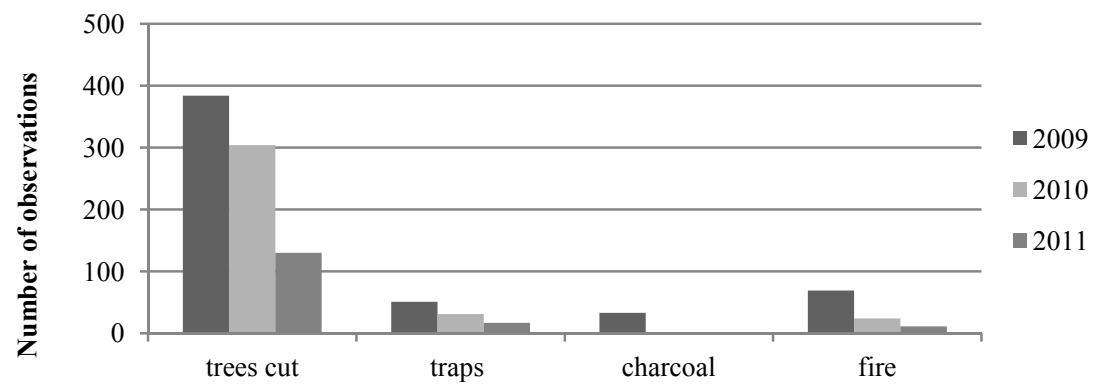

Figure 4: The number of threats observed during patrols in the conservation zone.

As the local dependency on wood from natural forests continues, the Project has adopted a strategy to encourage the local population to obtain wood from forests that are outside the conservation area but in proximity to villages. Capacity building with the local communities on management of these forested areas is also carried out. The realization of these activities has led to a decrease in the number of illegal logging instances observed within the conservation area and areas not managed by communities and an increase in wood collected from areas under community management. From 2009 to 2011, logging in the conservation area decreased from $40 \%$ to $13 \%$ and logging in areas managed by communities has increased from $53 \%$ to $95 \%$ (Figure 5 ). 


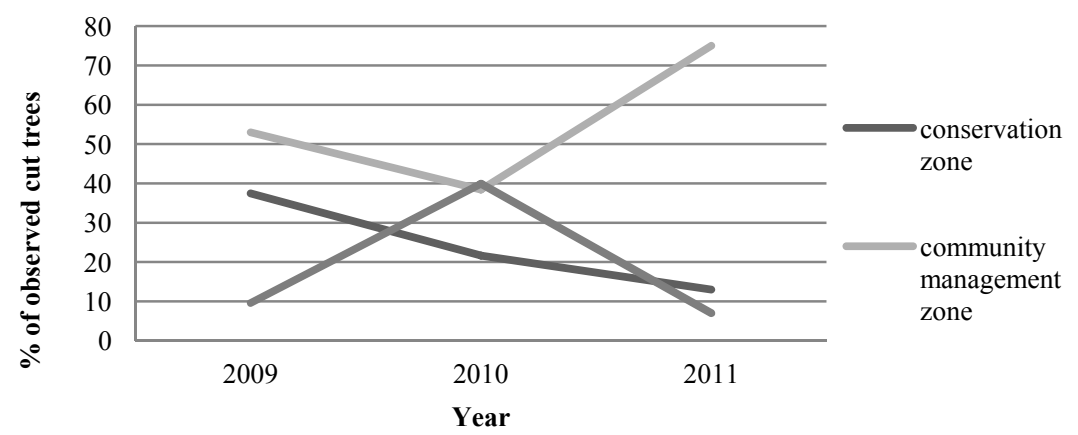

Figure 5: $\quad$ Number of observed cut trees.

\section{Discussion}

\subsection{The mine region}

The biological inventories conducted in the proposed CFAM suggest the high suitability of this site for linking the mine conservation area to the CAZ. Species inventoried are similar to those found in the surrounding conservation areas (mine conservation area and the CAZ) and thus the corridor is an effective bridge to maintain gene flow. However, several important threats to the corridor were also identified. Further work in conservation awareness with the local population needs to be implemented to secure the future viability of the CFAM. Furthermore, once temporary protection is assured for the corridor a series of management plans, public consultations and social compliance documents need to be elaborated to move forward in attaining permanent protected status for the CFAM.

Activities aimed to improve management and rehabilitate the Torotorofotsy Ramsar site are well underway. Moreover, many steps have been taken to work in collaboration with local authorities to assure conservation of the site. As there are currently no specific laws pertaining to the management of Ramsar sites in Madagascar, the government has committed to developing a set of strategies in order to include Ramsar sites as part of the National protected areas system of Madagascar (SAPM).

The creation of a protected forest corridor and the implementation of an improved management plan for Torotorofotsy will contribute to the long term conservation of forests linking the mine conservation area to the CAZ. This area is of high conservation importance due to the high level of biodiversity and species endemism. Furthermore, due to its location at the southern end of the CAZ, protection of this area can buffer against further degradation of the east coast forest corridor.

\subsection{The mine area forest management plan}

According to the Malagasy Ministry of the Environment [17], rural population poverty leads to increased dependence on natural resources. Moreover, in order to decrease pressures on natural resources, the availability of alternative animal proteins and 
sources of income need to be addressed. In order to start providing both alternative food sources and income generating activities, fish, chicken and beekeeping projects for the local communities located within the mine lease are planned.

Within the conservation area, the objective is to achieve a decrease and/or total elimination of illegal activities such as hunting of protected species and illegal logging. Alternatively, the Project has worked with the local communities both via awareness programs and the installation of community management areas that include reforested zones, in order to decrease pressure on the natural resources within the conservation area. The results of the conservation area patrols suggest that the strategy is effective as a decrease in the use of the conservation area for wood, protein and charcoal has been observed. The use of patrols has also proved to be an effective means to stop the illegal exploitation of protected species as has been shown for critically endangered turtles located in southwestern Madagascar [18].

The results of the forest management plan suggest that engaging local communities in alternative activities such as seedling production and promoting conservation awareness can be effective in decreasing pressure on natural resources. However, long term monitoring of the local population and zones under local management is necessary to assure that obligations are upheld. Furthermore, plans to implement income generating activities such as bee keeping and fish farms are in the process of being developed. The combination of raising awareness and providing an alternative to dependence on natural resources for maintaining livelihoods is hoped to contribute to the long term conservation of the forests surrounding the mine footprint.

\section{Conclusion}

The landscape approach to forest management in the mine area and region is based on the harmonization of conservation and economic activities related to use of natural resources. Connectivity between habitats for conservation and the clustering of areas for economic activities in locations close to villages has lead to the creation of a spatial zoning system that aims to address both the needs of the local community and the Project's biodiversity obligations. The establishment of zones as a regional approach to forest management has also facilitated negotiations with stakeholders and the implementation of activities related to forest management. Although the ultimate success of the landscape approach can only be evaluated over the long term, proximate measures show positive results in relation to pressures on the natural resources located in the conservation areas around the mine footprint due to the implementation of forest management activities.

\section{References}

[1] Goodman S.M., Biological research conducted in the general Andasibe region of Madagascar with emphasis on enumerating the local biotic diversity, Malagasy Nature, 3, pp. 14-34, 2010.

[2] Ministère de 1'Environnement et des Forêts, Decree $n^{\circ} 99-954$ on December 15, 1999 changed by decree $n^{\circ} 2004-167$ on February 03, 2004 
about the « mise en compatibilité des investissements avec l'environnement (MECIE) », République de Madagascar, 1999. http://www.meeft.gov.mg/

[3] Office Nationale de l'Environnement, Environmental Management and Social Development Plan for the Ambatovy Project, République de Madagascar, December 2006.

[4] Ambatovy Project, Volume J: Biological appendices. Environmental assessment Ambatovy Project, The Ambatovy Project, Antananarivo, 2006.

[5] International Finance Corporation, Performance Standard 6: Biodiversity Conservation and Sustainable Natural Resource Management (Chapter 7). International Finance Corporation's Performance Standards on Social \& Environmental Sustainability. World Bank Group, April 2006.

[6] Dickinson S., Berner P., Ambatovy Project: Mining in a challenging biodiversity setting in Madagascar, Malagasy Nature, 3, pp. 2-13, 2010.

[7] Comité technique du Corridor Ankeniheny-Zahamena, Plan d'aménagement et de gestion de la Reserve des Ressources Naturelles Ankeniheny-Zahamena. République de Madagascar, 2009.

[8] Association Mitsinjo Andasibe, Final report on Prolemur simus survey in the Analamay Mantadia forest corridor, unpublished report to the Ambatovy Project, April 2011.

[9] Dolch R., Fiely J. L., Ndriamiary J., Rafalimandimby J., Randriamampionona R., Engberg S. E., Louis E. E., Confirmation of the greater bamboo lemur, Prolemur simus, north of the Torotorofotsy wetlands, eastern Madagascar. Lemur News, 13, pp. 14-17, 2008.

[10] Noss R. F., A regional approach to maintain diversity. BioScience, 33 (11), pp 700-706, december 1983.

[11] Nguinguiri J-C., Les approches participatives dans la gestion des Ecosystèmes Forstiers dans l'Afrique Centrale. CIFOR occasionnal paper $\mathrm{n}^{\circ} 23$. Central for International Forestry Research, Indonesia, July 1999.

[12] BIODEV Madagascar, Final report on biological assessment in the Analamay Mantadia forest corridor, unpublished report to the Ambatovy Project, April 2011.

[13] RAKOTONIRINA J-E. Final report on biological assessment in the Analamay Mantadia forest corridor, unpublished report to the Ambatovy Project, July 2011.

[14] CIREF, MITSINJO, TARATRA, Projet Ambatovy, Mise à jour du plan d'aménagement du site de Torotorofotsy, with its annexes. Madagascar, 2009.

[15] Programme Jèkasy - Délégation d'Intercooperation au Sahel, Capitalisation des expériences du programme Jèkasy dans le domaine de la gestion des ressources naturelles et des bas-fonds, DIC-PT N³8, 2009.

[16] Randrianjafy Z. J. N., Guide pratique pour réussir son reboisement à Madagascar, Sept. 2009. http://www.tanisiaina.com/

[17] Ministère de l'Environnement, Programme environnemental III Document stratégique, République de Madagascar, 2002.

[18] Observatoire National de l'Environnement et du secteur forestier (ONESF). Le contrôle forestier. online http:/www.osf.mg/rapport.php 